\title{
Vidyodaya Journal of Humanities and Social Sciences
}

VJHSS (2022), Vol. 07 (01)

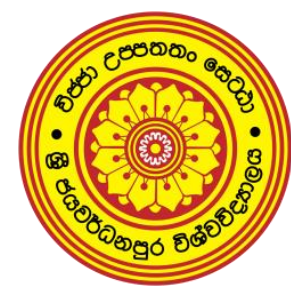

\section{Practices Followed to Manage Plastic Waste including Shopping Bags and Lunch Sheets in Sri Lanka: A Preliminary Study in Western Province}

\author{
S. P. Fernando*1, I. V. Kuruppu², G. V. N. Aiome ${ }^{3}$, D. M. A. C. Dissanayaka ${ }^{4}$ and \\ W. A. A. S. Wijesinghe ${ }^{5}$ \\ 1,3,4,5Hector Kobbekaduwa Agrarian Research and Training Institute, Ministry of Agriculture, Sri \\ Lanka, ${ }^{2}$ Faculty of Agriculture and Plantation Management, Wayamba University, Sri Lanka
}

\section{Article Info}

\section{Article History:}

Received 02 July 2021

Accepted 21 August 2021

Issue Published Online

01 January 2022

\section{Key Words:}

Best Practices

Plastic Waste

PBLS

*Corresponding author

E-mail address:

sangeeth.nature@gmail.com

Journal homepage:

http://journals.sjp.ac.lk/i ndex.php/vjhss

http://doi.org/10.31357/ fhss/vjhss.v07i01.02

VJHSS (2022), Vol. 07

(01), pp. 24-43

ISSN 1391-1937

ISSN 2651-0367 (Online)

(C)Faculty of Humanities and Social Sciences 2022

\begin{abstract}
Although plastics have made the workings of our lives easier, it has created many different environmental and social problems due to poor management practices. The problem of plastic waste has been exacerbated due to various regulations that have been introduced from time to time for the sustainable management of plastic waste. However, those are not properly implemented. The main objective of this study is to examine the best practices in Sri Lanka for the management of plastic waste, including shopping bags and lunch sheets (PBLS). Further, the study illustrated the prevailing and possible alternatives for polythene products in Sri Lanka and weaknesses in the identification of alternatives. The study was conducted in the Western Province covering three districts: Colombo, Gampaha and Kalutara. Data collection was conducted through different structured questionnaire surveys, key informant interviews and a major workshop from a sample of 1314 respondents. Results revealed that 59\% of households in the survey confirm that they were discouraged from switching to alternatives as a result of freely available low-density polyethylene (LDPE) bags in the market. Also, 67\% of the households and $74 \%$ of the supermarkets pointed out that, the current polythene bag usage was higher prior to the ban, due to the poor strength and quality of the bag. Further, the study reveals that 'Extended Producer Responsibility (EPR)' has the potential to influence material management systems and prevent pollution and has been successfully tested in many countries around the world.
\end{abstract}




\section{Introduction}

Plastic is a synthetic polymer made from crude oil. Plastic products including polyethylene bags and lunch sheets (PBLS) have become indispensable today for various reasons such as convenience, low-cost, impregnability to water, versatility, ease of manufacture and availability (Nielsen et al., 2019). The highest per capita annual consumption of plastics in the world is recorded in the United States and Europe at about $68 \mathrm{~kg}$ and $50 \mathrm{~kg}$, respectively. Japan and China have the highest per capita annual plastic consumption in the Asian region at 46 $\mathrm{kg}$ and $38 \mathrm{~kg}$, respectively. In India, Sri Lanka and Bangladesh the value is around $8 \mathrm{~kg}, 6 \mathrm{~kg}$ and $3.7 \mathrm{~kg}$ per year respectively (Mourshed et al., 2017). Furthermore, Gunaratne (2012) has revealed some information on the future trends in the use of plastics in Sri Lanka. Accordingly, polystyrene would be the least consumed plastic material in the year 2025 while polyethylene would be the most consumed one. He has also pointed out that about $51.16 \%$ of the plastics to be imported in 2025 will be wasted. At present, about 500,000 metric tons of plastic / polyethylene is imported to Sri Lanka annually and about $70 \%$ of it is used for domestic purposes. In addition, Sri Lanka earns about USD 2 million a year in foreign exchange from plastic imports and exports (Fernando, 2019).

Although the production of plastic waste has increased rapidly over the years due to the increased use of plastics in various fields, its management technology is still not well developed. Although per capita annual plastic waste production in developed countries is high, it is well managed. China, India and other low- and middle-income countries produce large amounts of waste in relation to their vast populations and are highly inefficient in managing them (Vanapalli, 2019). According to Gunaratne (2012), although plastic waste has a severe impact on the ecosystem of Sri Lanka, plastics play a significant role in the country's economy and provide social benefits by providing employment opportunities to the society. It is clear that the coast of Sri Lanka has also been severely polluted by plastics over the past decade and its severity is increasing day by day and immediate action needs to be taken (Kariyawasam, 2019). Along with the production of plastics, the generation of plastic waste is also increasing rapidly. The main challenge is whether all states in the world have the capability to successfully formulate plastic waste management strategies with increasing plastic generation. Anyhow, most developing countries are struggling with waste management due to the gradual increase in the rate of waste generation. However, it is clear that increasing the use and production of plastics in relation to developing and emerging economies is critical as the segregation of infrastructure for waste management may not grow at an appropriate rate to keep pace with rising levels of plastic waste (Palugaswewa, 2018). In Sri Lanka, too, a number of policy tools have been developed over the past two decades, but they have not yet been adequately facilitated. Although the per capita annual plastic consumption in Sri Lanka is lower than in the United States and Europe, due to the lack of technical, financial and expertise relative to those countries, considerable effort is required for plastic management (Mourshed et al., 2017).

\subsection{Research problem, aim and research questions}

Sri Lanka has been facing various environmental disasters for a long time due to improper management of plastic waste. In the meanwhile, new laws came into gazetted effect on September $01^{\text {st }} 2017$ aiming at minimising the above issues prior to a full ban on PBLS in September 2017, which led to a huge uproar within the society. While some applauded the step, pointing at the sunny side of the ban on the environment, others protested, for the lack of alternatives and the economic blow it may have on their 
livelihood. Almost four years on, has Sri Lanka successfully overcome its reliance on polythene and plastic? Sri Lanka does not yet have a pre-determined long-term proper plan or methodology for plastic waste management. The problem of plastic waste has been exacerbated due to the apparent lack/gap in the existing policies for plastic waste management as well as the problems with their implementation. It aims to explore important policy approaches that can be applied in Sri Lanka as long-term solutions to plastic waste management, as well as different issues addressed to different parties. Still, enough study with primary data collection hasn't been conducted in Sri Lanka to find the answers for questions arising following this major step. The overarching objective of this study is to examine the best practices followed to manage plastic waste including shopping bags and lunch sheets in Sri Lanka. This is done in order to suggest strategies to overcome barriers for sustainable plastic waste management in the country.

The research questions that result in specific objectives for the study are as follows:

1. What are the plastic waste disposal methods followed by the public?

2. What are the disturbances and limitations prevailing for the plastic waste management?

3. What are the best practices followed by the locals and foreigners to manage plastic waste?

\section{Materials and Methods}

\subsection{Selection of Study Location}

Waste generation rate depends on various factors such as population density, economic status, level of commercial activity, culture and lifestyle of the people in the area. Hikkaduwa et al., (2015) point out that about 3242 metric tons of waste is generated daily in Sri Lanka and 1783 metric tons of it is generated from the Western Province which includes 1284 MT collected from Colombo District. Furthermore, according to him, $10.50 \%$ of these wastes are composed of polyethylene and other plastic wastes, making it the second largest contributor to waste. Also, according to Gunaratne (2012), polyethylene will be the most consumed plastic material by 2025 . Also, a large number of manufacturers and sellers of polythene and other plastics are concentrated in the Western Province (SLEDB, 2019). That trend is likely to spread to other parts of the country. Therefore, the study was conducted in Colombo, Gampaha and Kalutara districts in the Western Province. Accordingly, five Divisional Secretariats (DSs) were selected from each district covering rural, semi-urban and urban segments.

\subsection{Sample Composition and Data Collection}

Several categories of respondents were carefully selected using mixed reactions, both probability and non-probability sampling techniques were used to ensure the richness of the data for the purpose of achieving the specific objectives. Here, a variety of tools has been used to explore the plastic waste disposal methods by the public, to identify the disturbances and limitations prevailing for plastic waste management, and to study the best practices in Sri Lanka and abroad for plastic waste management. Hence, cluster sampling with two stage along with purposive and random sampling techniques were adopted. Both primary and secondary data were used for the study. Primary data was collected through different pre-tested structured questionnaires for each respondent category. The planned total sample size was 1317 . However, the study was able to capture only 1209 respondents for the survey due to ground level concerns (Table 1). 
Table 1. Sampling Framework and the Purpose of Sampling

\begin{tabular}{|c|c|c|c|c|}
\hline $\begin{array}{l}\text { Respondent } \\
\text { Category }\end{array}$ & District & $\begin{array}{c}\text { Sample } \\
\text { Size }\end{array}$ & $\begin{array}{c}\text { Data Collecting } \\
\text { Tool }\end{array}$ & $\begin{array}{l}\text { Main Criteria } \\
\text { Assessed }\end{array}$ \\
\hline \multirow{4}{*}{ Consumers } & Colombo & 220 & \multirow{16}{*}{$\begin{array}{c}\text { Pre-tested } \\
\text { structured } \\
\text { questionnaires } \\
\text { survey }\end{array}$} & \multirow{4}{*}{$\begin{array}{l}\text { As a rational } \\
\text { consumer who } \\
\text { uses plastic } \\
\text { products }\end{array}$} \\
\hline & Gampaha & 225 & & \\
\hline & Kaluthara & 248 & & \\
\hline & Total & 723 & & \\
\hline \multirow{4}{*}{ Households } & Colombo & 64 & & \multirow{4}{*}{$\begin{array}{l}\text { As a household } \\
\text { who uses plastic } \\
\text { products in } \\
\text { domestic use }\end{array}$} \\
\hline & Gampaha & 64 & & \\
\hline & Kaluthara & 64 & & \\
\hline & Total & 192 & & \\
\hline \multirow{4}{*}{$\begin{array}{l}\text { Food court } \\
\text { owners/restaurateurs }\end{array}$} & Colombo & 53 & & \multirow{8}{*}{$\begin{array}{l}\text { As actors in the } \\
\text { food supply } \\
\text { chain who use } \\
\text { plastic products }\end{array}$} \\
\hline & Gampaha & 53 & & \\
\hline & Kaluthara & 22 & & \\
\hline & Total & 128 & & \\
\hline \multirow{4}{*}{$\begin{array}{l}\text { Supermarket } \\
\text { personnel }\end{array}$} & Colombo & 10 & & \\
\hline & Gampaha & 09 & & \\
\hline & Kaluthara & 08 & & \\
\hline & Total & 27 & & \\
\hline $\begin{array}{l}\text { Polythene collectors } \\
\text { and recyclers } \\
\text { (Persons who have } \\
\text { registered at the } \\
\text { Central } \\
\text { Environmental } \\
\text { Authority) }\end{array}$ & $\begin{array}{c}\text { Every } \\
\text { district in } \\
\text { Sri Lanka }\end{array}$ & 139 & $\begin{array}{l}\text { Over the phone } \\
\text { questionnaire }\end{array}$ & $\begin{array}{l}\text { As actors in the } \\
\text { plastic industry } \\
\text { who collect and } \\
\text { recycle plastic } \\
\text { waste }\end{array}$ \\
\hline Total & & 1209 & & \\
\hline
\end{tabular}

Furthermore, key informant interviews and a major workshop were conducted to collect primary data. Key informant interviews were conducted for 75 key persons including government institutions, non-governmental organizations, material researchers, polythene manufacturers, supermarket chains, major food producers and entrepreneurs in order to learn the situation following the polythene ban. A major workshop was conducted in May, 2018 with the participation of different parties (nearly 30 parties) including government institutions, non-governmental organizations, material researchers, major food producers, polythene manufacturers, supermarket chains, grocery shops, food vendors, entrepreneurs, plastic collectors and recyclers as well as the general public to gather the current situation on PBLS in Sri Lanka and evaluate the possible path forward. Data collection was carried out from March 2018 to September 2020. Besides, the quantity and the price of polythene (low density polythene and high density polythene) imported to Sri Lanka from 2016 to 2018 was obtained from the Department of Customs to make an overview of the amount of plastic imported to Sri Lanka. Other secondary data were gathered from various 
secondary sources such as relevant institutional documents, websites, other national and international journal articles, periodicals and reports.

\subsection{Data Analysis}

The following things had to be carried out to analyze the best practices followed to manage plastic waste including shopping bags and lunch sheets in Sri Lanka.

a) Overview of the plastic waste disposal methods by the public

b) Exploration of the disturbances prevailing for the plastic waste management

c) Examination of the best practices followed by the locals and foreigners to manage plastic waste

d) Overview of the plastic waste disposal methods by the public

Categorical data analysis (cross tabulation) was mainly applied to analyze the data with SPSS. For analyzing the plastic waste disposal methods, consumers, households and food court owners/restaurateurs were interviewed respectively. Additionally, a few analysis was done to find whether there is a significant difference in the disposal of plastic waste, depending on the gender of the consumers and the area in which they live. Also, the focus here was on whether disposable polythene shopping bags will be reused before such disposal.

b) Exploration of the disturbances and limitations prevailing for the plastic waste management

The study examined how some of the barriers that have been shown to be barriers to plastic waste management in the literature review have affected the study-based stakeholders by categorical data analysis (cross tabulation). Furthermore, some legislations in the country for plastic waste management, especially the polythene ban implemented on 01st of September 2017 was explored using relevant gazettes. Also, the amount of plastic imported to Sri Lanka per year has a direct impact on plastic waste management. According to Gunaratne (2012), since polythene is the most imported type of plastic in 2025, the amount of polythene imported from 2016 to 2018 and the amount spent were used for this purpose.

c) Examination of the best practices followed by the locals and foreigners to manage plastic waste

The locally applied action policies for plastic waste management were analyzed by studying questionnaires, key informant interviews, a major workshop and through websites. Other national and international journal articles, periodicals and reports have also been used to study some of the successful policy tools that have been put in place to effectively manage plastics in some parts of the world.

\section{Results and Discussion}

\subsection{Plastic Waste Disposal Methods}

Under this section, study-based stakeholders such as households, consumers, and food court owners/restaurateurs were contacted to enquire about their methods for disposing of plastic waste. It was also attempted to find out if there was a significant difference in the disposal of plastic waste, depending on the gender of the consumers and the area in which they lived. Also, the focus here was on whether disposable polythene shopping bags would be reused before such disposal.

\subsubsection{Household and Consumer Behavior with regard to Plastic Waste Disposal}

Plastic waste disposal methods of household's vs whether polythene bags are reused or not were taken into consideration. Accordingly, 81 percent of households in the study sample burn their plastic waste while 18 percent of them handover them to the Municipal Council. The remaining one percent dump it in an open area. Moreover, 51 percent of households reuse the bags prior 
to disposing of those while 49 percent do not do so.

The plastic waste disposal methods of consumers in each district also were outlined. Different methods were practiced disposing the plastic waste and 61 percent of consumers were burning their waste while 37 percent hand over it to the Municipal Council. Moreover, plastic waste disposal methods of consumers based on whether polythene shopping bags are reused before disposing have been discussed. According to descriptive statistics, 67 percent of consumers who burn, reuse the polythene bags before disposing while 33 percent of consumers do not.

Plastic waste disposal methods of consumers based on gender have also been discussed. According to descriptive statistics in the study, 63 percent of females practiced burning as the waste disposal method while it is around 55 percent for males in Western province, Sri Lanka. But, according to Vineeshiya, et al., (2016) women tend to express higher participation in solid waste management than men in Balangoda urban council, Sri Lanka. In addition, plastic waste disposal methods of consumers based on the area in which they live have been considered. According to descriptive statistics, 82 percent of consumers living away from town/village practice burning as the waste disposal method while it is around 54 percent for those living in urban areas.

\subsubsection{Way of Disposing the Polythene Waste Accumulated in Food Courts}

The ways of disposing the polythene waste accumulated in food courts are discussed here. Accordingly, 87 percent of food court owner's handover their plastic waste to the Urban Council while seven percent of food court owners burn the waste polythene. Hence, the remaining six percent of food court owners have directed the plastic waste to recycling centres.

\subsection{Disturbances and Limitations prevailing for the plastic waste management in Sri Lanka}

Under this section, it is expected to identify barriers to plastic waste management. For the sustainable management of plastic waste, concepts such as $3 \mathrm{R}$ and $4 \mathrm{R}$ need to be properly implemented, so the focus is on the extent to which such concepts are currently being implemented in Sri Lanka. There is also a wide-ranging discussion on the extent to which plastics-related laws enacted in 2017 have contributed to plastic waste management.

\subsubsection{Legislations Related to Plastics in Sri Lanka}

There are six gazette papers published on September 01, 2017 based on the National Environmental Act, No. 47 of 1980, Order under Section $23 \mathrm{~W}$, regarding some polythene related products (Central Environmental Authority, 2017). In addition to aforementioned gazette statements, there is another gazette published by Consumer Affairs Authority based on Act, No. 9 of 2003. It states that: "no trader shall at the time of selling of goods levy any charge directly or indirectly on consumers for any type of bags/wrappers issued to the consumers" (Sri Lanka Consumer Affairs Authority, 2003).

\subsubsection{Government Support for Plastic Collectors and Recyclers}

Government support for the plastic collectors and recyclers to manage the plastic waste was found. According to descriptive statistics, 86 percent of plastic collectors and recyclers have not received any support (awareness or incentives) by the government. That means the government support for the recycling process is not adequate. There are 43 percent of collectors, 54 percent of recyclers and 3 percent both collectors and recyclers who did not receive any government support. Hence, only 14 percent of plastic collectors and recyclers claimed they received support 
(knowledge or incentives) by the government. Of them, 6 percent of respondents have received subsidy while 8 percent attended programmes for capacity building.

\subsubsection{Raids by CEA Officials on Supermarket Chains for Polythene Investigation}

Raiding helps trace illegal polythene products and it is vital to discourage the producers and sellers involved in these activities. Accordingly, the questionnaire survey conducted up to end of August 2018 revealed that 67 percent of supermarkets were investigated by the CEA officials. Around 63 percent of supermarkets out of the total supermarkets raided were checked only one time. Punitive measures were taken against offenders last year for violating polythene laws. Those first-time offenders were fined Rs. 10,000.00 while it was five times for repeating the offence. According to the key person interviews, observations and focus group discussions, CEA is in good stead in terms of the polythene raiding compared to year of 2018. The fine should be revised for raiding to be more effective. Consequently, CEA has to increase the frequency of raiding to limit the illegal producers, sellers etc. For this, more staff is needed, which is a constraint.

Yet, the researchers found quite a few limitations in the processes used in the detection of illegal products. The government has to rely on the importation certificates confirming legitimacy of the raw materials used in the manufacturing process, while having only limited resources and methods to check for banned substances in the finished products. It was also identified that the government sector, at present, has no laboratory facilities to test degradability of material, so as to confirm whether the required standards are met by the manufacturer.

\subsubsection{Perception and Experiences of Various Stakeholders following PBLS Ban in 2017}

\subsubsection{Households' Perception on PBLS Ban}

Under this, households' perception on PBLS based on the availability of bio-degradable products has been taken into account. According to descriptive statistics, 96 percent of households said that bio-degradable products which can be used for polythene lunch sheets are not available at the market while only four percent of households replied in the affirmative. Hence, 28 percent of the total households directly said that banning is not realistic while 20 percent of the total households responded in favor of the move and claimed people will look for alternatives. Moreover, 35 percent of total households while responding positively over the ban recommended that the alternatives should also be introduced. Further, households have expressed their perception on the strength of the prevailing bags in each district. Accordingly, 67 percent of households' perception on the new bag is its strength is poor and 27 percent claim that the strength is moderate.

\subsubsection{Consumers' Perception on PBLS Ban}

Under this, consumer perception on the success of the PBLS ban has been considered based on the districts. According to descriptive statistics, 42 percent of customers said that the PBLS ban is not a success, as the number of bags used has risen (after the ban). The inferior strength of the newer grocery bags had resulted in an apparent increase in polythene bag use and the higher price of alternative products for grocery bags and lunch sheets has made the shift to ecofriendlier options less attractive. As well, 18 percent of customers said the ban is not realistic due to the unavailability of suitable alternatives. 60 percent of consumers claimed that the PBLS ban is not a success. 
Only 20 percent of customers admitted that it is a success, as they start using low density polyethylene (LDPE) bags and biodegradable lunch sheets.

\subsubsection{Supermarket Chains' Main Experience and Idea on Current Polythene Bag}

Supermarkets' experience and idea on current polythene bag was investigated. Accordingly, 74 percent of supermarket authorized persons said strength of the polythene bag which came after the ban is low. Similarly, 17 percent said that they received complaints from their customers on the bags.

\subsubsection{Polythene Manufacturers' Perception on PBLS Ban}

According to the polythene manufacturers, although large-scale factories comply with the polythene law, it is difficult to control the production of unregistered domestic industrialists. In addition, lunch sheets, produced by LDPE released to the market in the name 'biodegradable' tag is another problem that is yet to address. On the other hand, bio-degradable additives are costly. Therefore, producers tend to use less amount of additives, which would lead to less effectiveness of degradable material. Besides, when interviewed, the polythene manufactures said that the government should have discussed the matter (ban) with them before enforcing.

\subsubsection{All Ceylon Canteen Owners' Perception on PBLS Ban}

Mr. Asela Sampath, President of the Sri Lanka Canteen Owners Association charged that following the ban, a bio-degradable lunch sheet was introduced but with poor discrimination. Consequently, most traders were tempted to sell LDPE lunch sheets in the guise of biodegradable lunch sheets at a high price in the market. So he stressed the need for a mechanism to identify the genuine biodegradable lunch sheets.

\subsubsection{Industrial Development Authority's Perception on PBLS Ban}

Mr. B.K. Tharanga of the Industrial Development Authority said that polythene shopping bags and lunch sheets had been promoted as a small-scale industry by their institution. Hence, industrialists were facilitated to obtain bank loan facilities to uplift their industries. However, owing to the ban, the small industrialists had been severely inconvenienced with the case of high-density polyethylene (HDPE) shopping bags and lunch sheets. Since the Authority encouraged the small-scale industries to promote polythene related products, by no means they can help the law enforcing authorities to nab the culprits who violate the ban. However, the bank has stopped issuing loans to discourage the small-scale polythene manufacturers to support the law. He also said they direct them to take up alternative livelihoods as much as possible.

\subsubsection{Some Stakeholders' Perception on Alternatives}

\subsubsection{Food Vendors' Perception on Alternatives}

Here, suitability of bio-degradable polythene for food wrapping in food courts has been questioned. Accordingly, around 74 percent of food vendors (canteen owners and bakery owners) said it is difficult to use biodegradable polythene in food wrapping.

\subsubsection{Main Obstacles Faced by Consumers when Using Alternatives}

Here, the main obstacle faced by consumers when biodegradable alternatives are used in each district was in focus. Accordingly, majority of customers (32 percent) said that the price of every alternative is high. 


\subsubsection{Main Reason for not Using the Eco- friendly Alternatives by Households}

The main reason for not using the ecofriendly alternatives in each district has been identified. Accordingly, majority of households (59 percent) said the free availability of LDPE bags in the market discouraged them to switch to alternatives. Besides, 24 percent expressed that 'polythene bags are easy to use'. Five percent of households claimed the less availability of alternatives as a reason not to use the alternatives.

\subsubsection{Details on Polythene Imported to Sri Lanka}

The global production of plastic is currently estimated to be around 300 million tons per year, while plastic pollution in the marine environment alone is estimated to be around 9.5 million tons, with a staggering 1.5 million tons ending up in the ocean annually (The International Union for Conservation of Nature, 2018).

In this study, the quantity and the price of polythene (low density polythene and highdensity polythene) imported to Sri Lanka in the past three years was obtained from the Department of Customs and shown below. Specific gravity $<0.94 \mathrm{~mm}$ denotes low density polythene while $>=0.94 \mathrm{~mm}$ denotes high density polythene.

Table 1. Socio-demographic features, crops grown and farm activities of sampled women farmers

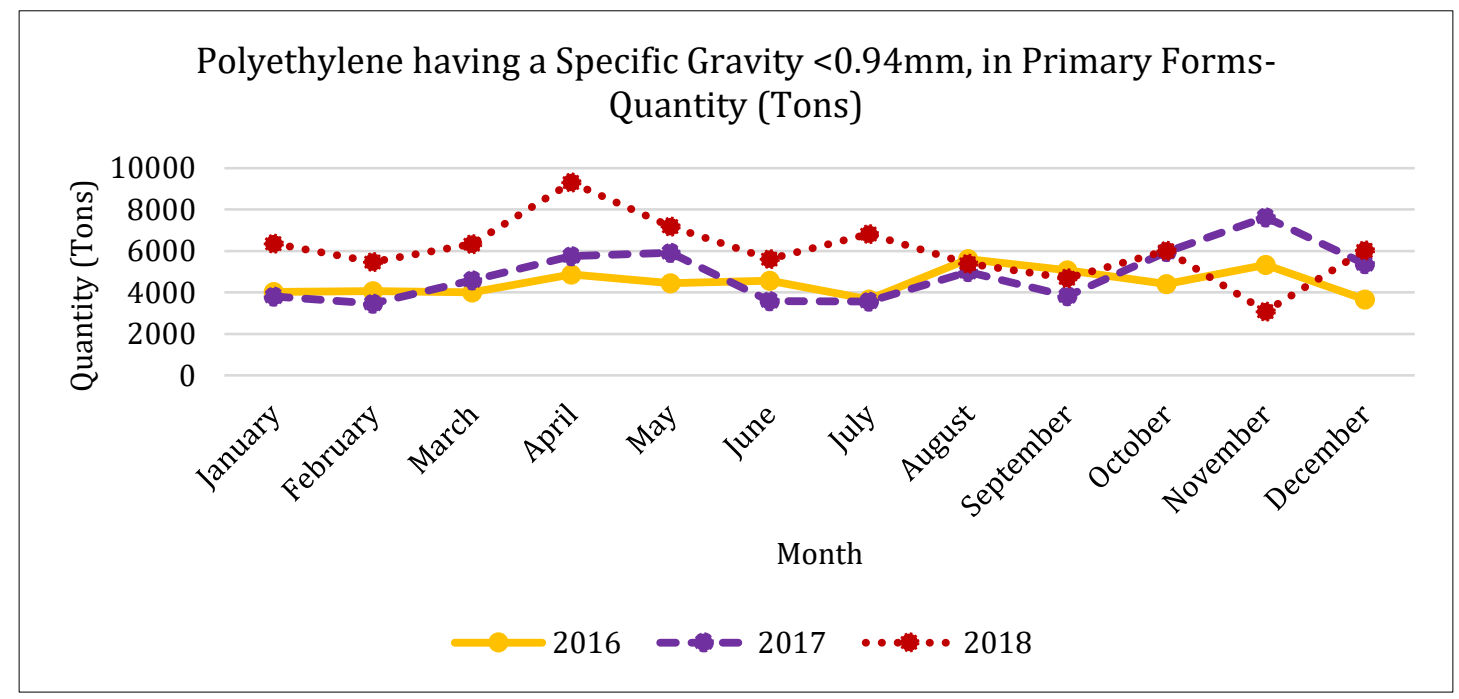

Figure 1. Total Quantity of Low-Density Polyethylene (LDPE) Imported to Sri Lanka from 2016 to 2018 
From the beginning of November 2017 to end of October 2018, Sri Lanka has imported around 76,500 Mt of LDPE. Besides, it is clear that, every month, this particular quantity of the LDPE has significantly increased in 2018 in comparison to previous years.

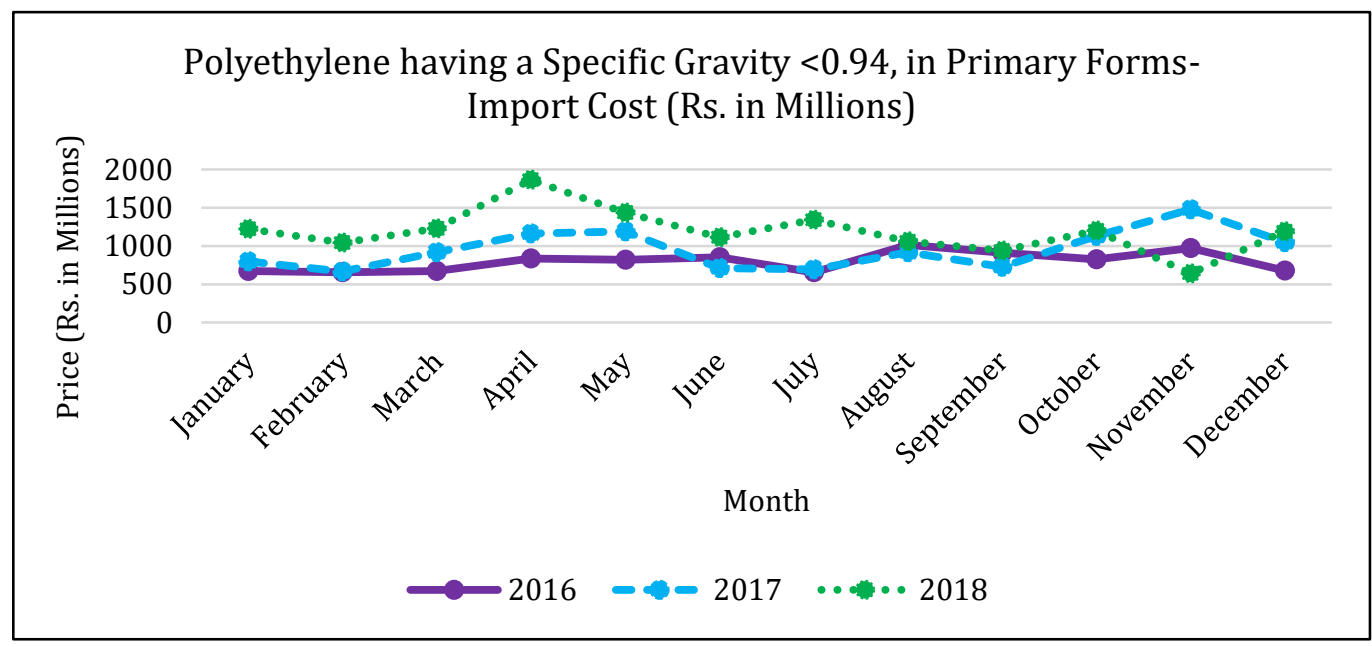

Figure 2. Total Expenditure of LDPE Imported to Sri Lanka from 2016 to 2018

From November 2017 to end of October 2018, Sri Lanka has paid Rs. 15 billion on LDPE. Hence, it is clearly visible that the expenditure on LDPE every month has significantly increased in 2018 in comparison to previous years.

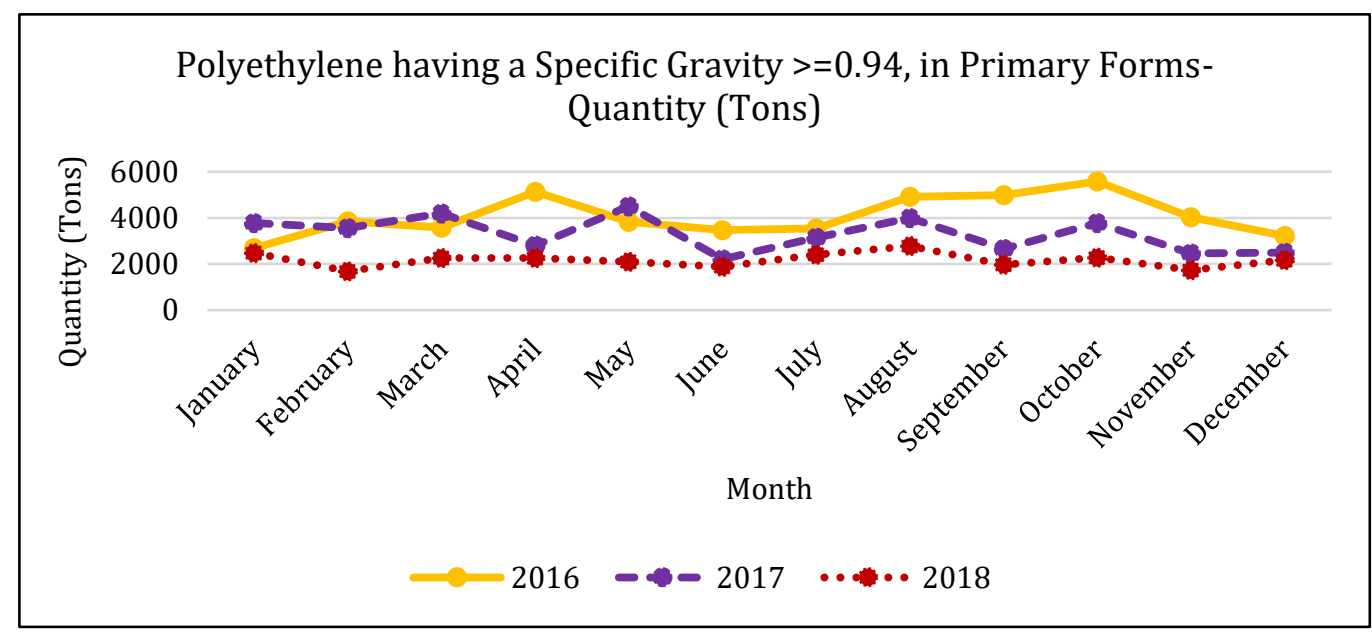

Figure 3. Total Quantity of High-Density Polyethylene (HDPE) Imported to Sri Lanka from 2016 to 2018

From November 2017 to end of October 2018, Sri Lanka has imported around 27,500
Mt of HDPE and the quantity has significantly decreased in 2018 in comparison to previous years. 


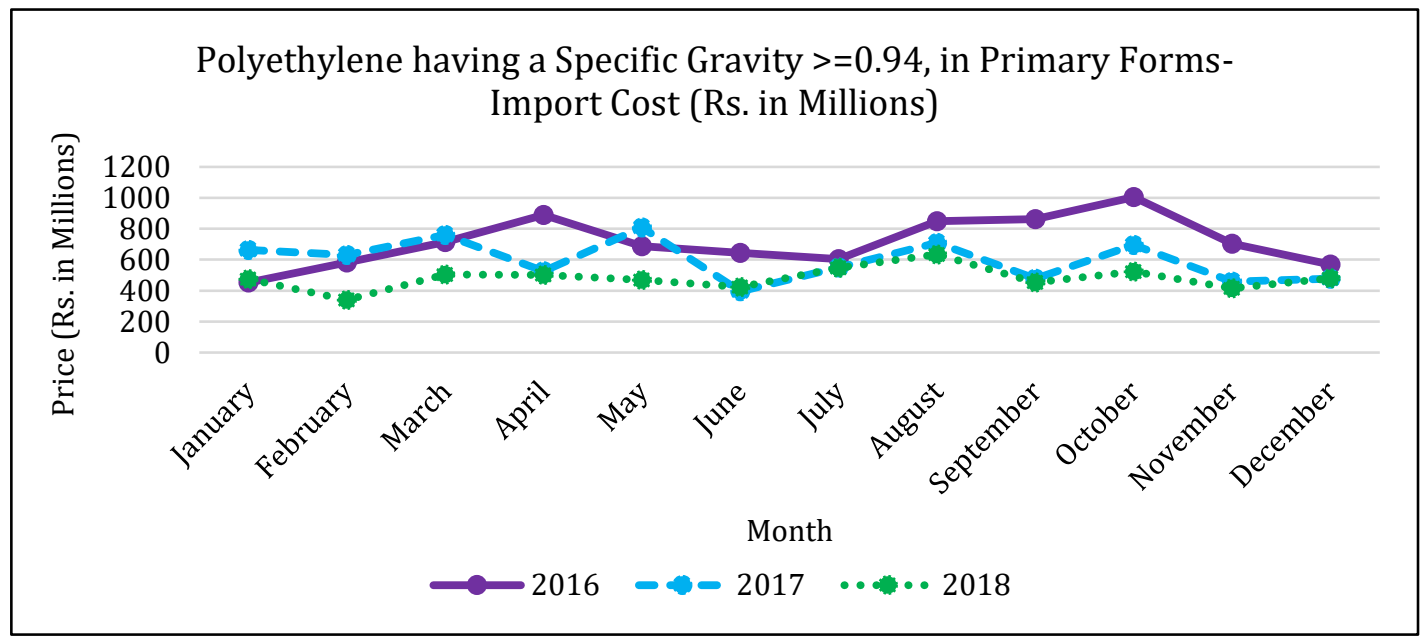

Figure 4. Total Expenditure of HDPE Imported to Sri Lanka from 2016 to 2018

From November 2017 to end of October 2018, Sri Lanka has paid around Rs. 6 billion on HDPE. Thus, it is clear that the expenditure on buying HDPE every month has significantly decreased in 2018 in comparison to previous years.

\subsection{Best practices followed by the locals and foreigners to manage plastic waste}

Here, the best practices to be followed by locals and foreigners in managing plastic waste are discussed in detail. The policy tools adopted by one country depend on the social, economic and environmental factors of the country and a policy tool adopted in one country may fail in another country. Some policy tools can support paradigm shifts. Therefore, before introducing a new policy tool in any country, it should be thoroughly analyzed. This section explores the best practices used by study-based stakeholders in the proper management of plastic waste. In addition, it is hoped to discuss the extent to which the contents of existing policies in Sri Lanka as well as existing policies in other countries can be applied to Sri Lanka.

\subsubsection{Best practices used by study-based stakeholders in the proper management of plastic waste}

\subsubsection{Prevailing and Potential Alternatives for PBLS}

This study found the prevailing and possible alternatives for polythene products in Sri Lanka and weaknesses in identification of alternatives. Although consumers use banana leaves, lotus leaves and other types of leaves instead of lunch sheets, there is no sufficient supply for the current demand. In the meanwhile, Dr. Sujatha Weerasinghe a lecturer of the University of Colombo conducted a study applying bio technology to produce banana leaves in a large area to wrap food while gaining a bumper harvest. Therefore, amenable officers should promote such programmes.

\subsubsection{Main Contribution of Supermarket Chains to Promote Eco-friendly Alternatives}

Under this, supermarket chains' main contribution to promote eco-friendly alternatives was investigated. Accordingly, 64 percent of supermarkets have promoted the cloth bags with its name printed on it while 14 percent of supermarkets award four-rupee discount from the total bill for a reusable bag. 


\subsubsection{Main Material Used by Households to Wrap Meals}

Under this, main material used by households to wrap meals has been identified. According to descriptive statistics, after the ban, 42 percent of total households said they use lunch boxes while 32 percent of total households said they use lunch sheets available in the market. Moreover, 15 percent of the total households have opted for banana leaves. Only one percent said they use lunch sheets made from HDPE. Despite their claim, it is hard to distinguish the HDPE lunch sheet from that is made of bio-degradable material.

\subsubsection{Remedies to Reduce the Polythene Waste in Food Courts}

Eco-friendly alternatives to polythene are sought to reduce the plastic and polythene usage. Accordingly, 45 percent of food courts out of the food courts in the study serve food in glass plates in place of lunch sheets. As well, nine percent of food courts use the biodegradable lunch sheets. With regard to banana leaves, six percent of food courts out of the total use them. Besides, there are 'kolapath' plates (areca nut leave plates), paper plates, lotus leaves used in food courts. However, the percentages are negligible.

\subsubsection{Value added plastic products made from post-consumer plastics}

A new type of plastic recycling businesses known as "upcycling" has emerged, which produces value added plastic products made from post-consumer plastics, such as flower pots, mats, and containers. For an example, Mr. Kumarasinghe in 2019, expressed that he engaged in a recycling business, and developed value added products from plastic waste for niche markets to ensure financial and environmental sustainability. Here, he collects clean polythene from local authorities in Gampaha district and manufactures many innovations including files, floor tiles, ceiling tiles, wallets that are not manufactured by many other recyclers.
Then, he effectively sells his products using social media networks and in addition goes to shopping malls and hotels to get proper value for his products.

This shows that there is still a lot of room for growth in the plastic recycling and recovery business. Also, plastic waste management helps to reduce the potential adverse effects on the environment by reducing greenhouse gas emissions by reducing the use of raw materials and fossil fuels. It also reduces the amount of waste going to landfills that are close to capacity and helps alleviate the challenge of obtaining alternative landfills for landfills.

\subsubsection{Best Practices on Plastic Waste Management in Sri Lanka}

During the study, Professor Jagath Premachandra, the University of Moratuwa was interviewed on the ban on polythene. The most important point in his comment was considering the $3 \mathrm{R}$ concept in garbage management. In addition, he further noted that the total ban on polythene is a very difficult process. On January 1, 2018, only four types of products under polythene were banned. It is essential that polythene users must be encouraged towards reuse of polythene. Recycling should be done as much as possible after use. Then, gradually, usage of polythene will decrease.

According to him, agricultural waste and waste products in the garment industry can be used for producing alternative bags. In addition, traditional ingredients such as cans and straws can be used for producing the alternatives. The University of Moratuwa is conducting a research to produce alternative bags with agricultural waste and waste products in the garment industry. There are several issues with regard to the production of biodegradable polythene. The process is heavily time consuming. Another issue in Sri Lanka is the absence of technical facilities to test the time taken by biodegradable polythene for complete degradation and 
decompose into carbon dioxide, water and humus. In addition, it is possible to make lunch sheets by using the polylactic acid imported for producing bio-degradable lunch sheets, mixed with starch (sugarcane, corn, rice) instead of HDPE and lunch sheets. These products are already being manufactured in countries such as India and England. Even if it is possible to use Oxo biodegradable, it must be mixed with heavy metals to direct decompose in the first stage. In this process, after it decomposes up to 90 percent, the remaining 10 percent is decomposed by soil microbes. In certain countries, this method is banned, but is a common practice in Saudi Arabia. According to Premachandra, Sri Lanka can produce polythene by using Oxo biodegradable as a raw material, if approved by the Sri Lanka Standards Institution. Nevertheless, it was not environmental friendly and he pointed out those heavy metals added at the initial stage of the process may be added to the environment.

The Asset Group of Companies in Sri Lanka followed a new technology to incorporate the plastic waste to produce asphalt for road surfacing. The new material has been tested via a pilot project, on a strip of road spanning 500 meters (Pilot section-300 $\mathrm{m}$ and Control section - $200 \mathrm{~m}$ ) from Ratmalana to Borupana. The company has collected and sorted non-recyclable plastic bags from municipal waste. Next, these have been cleaned, shredded to a permissible size and mixed with aggregates at $165^{\circ} \mathrm{C}$ temperature, within the asphalt batching chamber. Then, it has been applied for surfacing of roads less than $150{ }^{\circ} \mathrm{C}$ temperatures (Ada Derana, 2018). Nowadays, UK, Canada, Netherlands, Philippines and Indonesia are also practicing this technology and accordingly plastic waste can be managed while greatly reducing the cost of road construction by making the asphalt pavements more durable.

\subsubsection{Best Practices on Plastic Waste Management in Other Countries}

\subsubsection{Alternatives for Polythene Bags}

There is a range of alternatives to plastic bags. Supermarkets in Australia introduced biodegradable bags made from tapioca starch since 2003. According to Gogte (2009), though these bags closely resemble polythene bags, they decompose within three months. According to a study by Camann (2010), in the United States, canvas bags are as popular as paper bags. The study also has demonstrated that a fair amount of the consumers would be willing to pay a small fee for alternative bags if such a system was introduced. The amount of participants willing to pay for alternatives is larger than the amount of participant willing to pay for current plastic bags.

\subsubsection{Bioplastics from Waste Newspapers}

According to Agyeman (2014), with the aid of research and technology, the eco-friendly bags such as jute bags, cloth bags, paper bags and many other varieties have been initiated as alternatives to plastic bags. Further he mentioned that these bags are recyclable, reusable and have no harmful effects on the environment. According to a past study by Goswami et al., (2014), the solution to this problem is biodegradable bioplastics. In that study they have dealt with the making of bioplastics from waste.

Because newspapers possess cellulose, they have extracted cellulose from the waste newspapers by decomposing them. When decomposing happens, cellulose is crumbled into starch/glucose by a process called Cellulolysis which is done with the help of enzymes. Finally, bioplastics has been prepared in lab by starch/glucose. Moreover, they have mentioned that although bioplastics are generally derived from renewable biomass sources, such as vegetable fats and oils, starch or micro biota, there is a variety of materials that bioplastics can be composed of, including: starches, cellulose, or other biopolymers. Besides, bioplastics can be used for packaging 
materials, dining utensils, food packaging, and insulation.

Due to many countries and states like China, Ireland, South Africa, Uganda and San Francisco banning the plastic grocery bags responsible for so-called "white pollution" around the world, poly lactic acid (PLA) is poised to play a big role as a viable, biodegradable replacement. According to Goswami et al., (2014), bio-plastics are made by corn starch, potatoes starch or banana starch which is used by humans and animals for their living. So his suggestion is that instead of using starch excreted from eatable things, waste newspapers which are mainly made up of cellulose and those newspapers dumped into oceans for disposal should be used for producing bio-plastics. The production of bioplastics or biodegradable plastics is currently very low and it is estimated at around 4 million tonnes per year.

\subsubsection{Recycled Plastic Bottles in Concrete Blocks}

Safinia and Alkalbani (2016) conducted a study to scrutinize the possibility of using plastic bottles in concrete blocks in Oman. Accordingly, they revealed that in comparison to Omani hollow concrete blocks, the concrete blocks with plastic bottles are 57 percent higher in compressive robustness. Similarly, as emphasized by Maroliya (2012), hollow concrete blocks may be used as substitutes to bricks and traditional stones in the construction field. Furthermore, they impart an advantage of uniform quality as well as speeding in construction and the largest longevity. Maroliya (2012) further revealed that they are less expensive, consuming less cement and less involvement of labourers and so on. Additionally, they can be employed in various locales such as the interior walls, exterior wall bearings and columns, the compound walls, and retaining walls.

\subsubsection{Recycled Plastic Waste to Plastic Cement}

Jassim (2017) administered a research to peruse the possibility of producing plastic cement mixed with Portland cement and the effect of replacing sand by fine polyethylene waste with different percentage on the properties of product. He conducted the experiments with the help of the waste of polyethylene packages including bottle and food crates in the range of 10 percent to 80 percent by volume as a short fortification edifice. Thus, results infer that there is a possibility to fabricate plastic cement from polyethylene waste and Portland cement by using 60 percent and 40 percent, respectively. But, their density has decreased while ductility and the workability has enhanced, which lead to produce lightweight stuff.

Further, Rai et al., (2012) found that the workability and compressive strength were reduced due to partial replacement of sand by waste plastic flakes in varying percentages by volume to produce waste plastic mix concrete with plasticizer. Pezzi et al., (2006) found that the addition of polymeric material in fraction less than 10 percent in volume inside of cement matrix does not imply a significant variation of the concrete mechanical features. Binici et al., (2012) successfully used polyethylene bottle wastes in cement production and found that the ductility of concrete was improved. However, Marzouk et al., (2007) found that density and compressive strength of concrete decreased when the polyethylene terephthalate aggregate exceeded 50 percent by volume of sand. According to Dinesh et al., (2016), high strength bricks that possess thermal and sound insulation properties can be manufactured with the help of HDPE and polyethylene bags while mitigating the environmental pollution. 


\subsubsection{Plastic Waste for Road Construction}

Kashiyani et al., (2013) launched a study to find the use of plastic waste in road construction along with utilizing process. Accordingly, 60 percent of the plastic-waste collected in India has been recycled back into the materials for further processing into consumer products, while the balance is left unutilized before year 2000. Afterwards, plastic waste has been used by India in the construction of flexible road pavement. According to them, plastic would increase the melting point of the bitumen. As well with the help of the innovative technology, the construction of roads can be enhanced while mitigating the damage on the environment. They further disclosed that plastic roads would be a blessing for India during hot and extremely humid weather conditions where durable and eco-friendly roads will relive the earth from all types of plastic debris. In India, 52,000 tons of plastic waste is produced per year and several roads have been built in this manner using polymer-coated-bitumen aggregate.

\subsubsection{Management of Plastic Bags and Packaging}

Globally, an ever-growing number of countries are introducing laws and policies to reduce, discourage, or ban the use of certain types of packaging materials. Bashir (2013) in a study explored the plastic problem in Africa and according to that, 90 percent of garbage in Africa has rotten in public areas. Certain African countries such as Rwanda, Tanzania and Uganda have passed laws, banning or restricting the use of the ordinary plastic grocery bag. They have taken several actions to reduce exposure to plastic toxins. Further, African governments encourage people to refrain from plastic packages and store different items in containers such as reusable glass. Moreover, they are encouraged to use reusable bags or containers brought from home when marketing.

In the United Kingdom, people are encouraged to purchase reusable bags for life. Under a campaign, titled "Saving the Planet One Bag at a Time and Encourage Consumers to Reuse Them", a three-part plan was launched to encourage more people to change their bag usage habits (Camann, 2010). It aimed at gradual elimination of polythene bag usage at supermarkets.

The first part is called 'Remind', that involves displays throughout the stores reminding people to reuse bags and buy reusable ones, sometimes called "Bags for Life." Furthermore, thousands of cashiers have been trained to offer 'Bags for Life' for those who did not bring their own. The second part is called 'Reward,' in which customers are given points called 'Nectar Points' for buying reusable bags and reusing old plastic bags through the 'Nectar Point' Reward Programme. Since its beginning, over 300 million points have been rewarded. These points resemble electronic money that may be spent on an online Nectar store for various household items, entertainment, and even vacations. The final part of the programme is called 'Remove.' In October 2008, Sainsbury stopped providing free Polyethylene bags in all of its supermarkets (Camann, 2010).

Tesco, a British supermarket and merchandise giant introduced its 'Green Club-card Points' programme, which rewards customers for reusing bags. As a result of this programme, over three billion bags were saved within three years. Waitrose was one other supermarket in the United Kingdom which implemented a programme to encourage reusable bag use. Accordingly, they hid polyethylene bags from view and offer cheap "Bags for Life" to customers, and asked if customers need bags. Waitrose noticed about a 1100 percent increase in sales of 'Bags for Life', followed by a decline as customers started reusing them. At the same time, polyethylene bag usage has 
dropped by around 45-50 percent as customers used alternative bags (Camann, 2010).

In another instance, Ireland introduced a "Plas Tax"; a mandatory 20 cent tax on all polythene bags used in purchases. Consequently, Ireland's plastic bag consumption per person per year has dropped by 95 percent in less than a year. The initiative has changed consumers' habits and helped reduce the number of polythene bags used. Afterwards, the Australian government in 2008 has also imposed a tax on all polythene bags which resulted in a 90 percent decrease in polythene bag usage in the country in less than a year. Similarly, South Australia imposed its official plastic bag ban in May 2009. It has been the first state of Australia to do so. A progress report after six months of the ban and by late 2009, 200 million polythene bags had already been saved from use. Nearly 90 percent shoppers bring reusable bags with them to stores/shops, which is a 60 percent increase compared with the situation before the ban. Further, retailers in Australia may be charged a $\$ 5,000$ fine for offering polythene bags and, suppliers a $\$ 20,000$ fine for selling of polythene bags (Camann, 2010).

Denmark has also instituted a tax on bags and a more different approach has been followed here than Ireland. In 1994, Denmark has put a tax of 22 Danish Krone per kilo of plastic bags. This tax was included in the price charged to retailers and has cut plastic bag usage by 66 percent. Since, unlike Ireland, the tax has not been levied on consumers, it did not change consumer behaviour by as much as the Irish tax. The Danish market has collected around 170 million of Danish Krone so far and has used that money to fund many environmental projects (Gogte, 2009).

According to Camann (2010), San Francisco was the first city in the United States to ban plastic bags. The government introduced three options for supermarkets: biodegradability, reusability/recyclability and fines were imposed on violating the above. It was reported that approximately 127 million plastic bags were saved following the ban.

'Extended Producer Responsibility (EPR)' is an important policy tool that has the potential to influence material management systems and prevent pollution, and has been successfully tested in many countries around the world (McKerlie, 2006). For example, it is used as a key waste management policy tool to support the implementation of the European Waste Hierarchy (Filho, 2019). Furthermore, it has been used successfully to reduce single-use plastic waste generated by Canadian consumers (Diggle, 2020).

\section{Conclusion and Recommendations}

An interesting finding outlined in this research was the presence of an act that would have been a contributor to the excessive use of polythene grocery bags and lunch sheets over the years. Consumer Affairs Authority No. 9 of 2003 states that: "no trader shall at the time of selling of goods levy any charge directly or indirectly on consumers for any type of bags/wrappers issued to the consumers". This is well illustrated by the fact that $59 \%$ of households confirm that they were discouraged from switching to alternatives as LDPE bags available in the market were available for free. Another aspect of plastic waste management is the enforcement of laws regulating the manufacture, use, and disposal of polythene and plastics. Even if there are laws, strict enforcement and regular monitoring are needed to achieve the expected outcome. Our study found many concealed as well as blatant violations of environmental laws related to plastics, committed due to lack of awareness or disregard for them. This is indicated by the fact that 81 percent of the households based on the study use burning as a plastic waste disposal method and that lunch sheets made from LDPE are being marketed as 'biodegradable'. 
Sixty-seven percent of the households and 74 percent of the supermarkets interviewed in the research had pointed out that their bag usage is higher than that was prior to the ban due to poor quality of the current one. Also, 42 percent of consumers said that the PBLS ban is not a success, as the number of bags used has risen (after the ban). The inferior strength of the newer grocery bags had resulted in an apparent increase in polythene bag use and the higher price of alternative products for grocery bags and lunch sheets has made the shift to eco-friendlier options less attractive. As well, 18 percent of consumers said the ban is not realistic due to unavailability of suitable alternatives. Altogether 60 percent of consumers claimed that the PBLS ban is not a success.

According to manufacturers of grocery bags, compared to the previously used HDPE, LDPE based bags used at present were not only of poor strength, but also incurred a higher production cost while being more difficult to recycle after use. A similar issue was raised with regard to the new lunch sheets by 74 percent of the food vendors surveyed, that these lunch sheets were easily damaged, leading to leaking of wrapped food while making the wrapping process more difficult compared to the polythene sheets used before.

Enforcement of the law by the government would play a major role in making the "polythene ban" effective. According to the Central Environmental Authority, an increasing number of inspections and raids had been carried out at retail shops, supermarkets and manufacturing facilities to detect illegal polythene products. Yet, the researchers found quite a few limitations in the processes used in the detection of illegal products. The government has to rely on the importation certificates confirming the legitimacy of the raw materials used in the manufacturing process, while having only limited resources and methods to check for banned substances in the finished products. It was also identified that the government sector, at present, has no laboratory facilities to test degradability of material, so as to confirm whether the required standards are met by the manufacturer. When the plastic collectors and recyclers registered at the Central Environmental Authority were interviewed, it was found that 42 percent of those contacted had quit the trade. Of those still operating, 86 percent lamented on the minimal assistance or encouragement by the authorities for continuing their industry.

This study found the prevailing and possible alternatives for polythene products in Sri Lanka and weaknesses in identification of alternatives. Although consumers use banana leaves, lotus leaves and other types of leaves instead of lunch sheets, there is no sufficient supply for the current demand. Further, study revealed that 'Extended Producer Responsibility (EPR)' that has the potential to influence material management systems and prevent pollution, has been successfully tested in many countries around the world (McKerlie, 2006).

Amendment or abolition of Consumer Affairs Authority Act, No. 9 of 2003 could pave the way for retailers and food vendors to introduce a system of charging the customer for any bags or wrappers they request, while competitively promoting the use of biodegradable alternatives and even the reuse of polythene bags. Even though certain supermarkets in Sri Lanka have already introduced commendable steps such as providing loyalty card points and discounts for bringing own reusable bag, it is suggested taking it a step further to bring in a points system for reusing used plastic bags as well. If the government could intervene and negotiate the use of such incentive programmes across all supermarket chains in Sri Lanka, it could be a positive step towards limiting the usage of plastic bags in the country.

It was also apparent that the existing fines to punish the offenders fall short of any effect. Therefore, it is recommended to increase the 
fines to create more impact in the society. A slogan hailed by other countries is 'polluter pays, by way of extended producer responsibility'. In this approach, producers are held responsible for the plastics and packaging they manufacture or use within the entire life cycle of the product. The producers themselves would have to take steps to establish a system that recovers and manages the waste generated from their product.

Sri Lanka has a long way to go in polythene waste management, let alone overall waste management, before it reaches a satisfactorily sustainable state. It is hoped that authorities would implement future steps in this regard in a more rational manner, with prior consultation with experts, while taking into consideration opinions of relevant stakeholders and openly communicating the approach and its basis to the public, so as to manage the plastic waste in Sri Lanka.

Acknowledgement: Authors wish to express their profound gratitude to all stakeholders in both public and private entities for the support given.

\section{References}

Ada Derana (2018). Waste Plastic for Road Surfacing? Retrieved October 14, 2018, from:

http://bizenglish.adaderana.lk/wasteplastic-for-road-surfacing/

Agyeman, C.M. (2014) 'Consumers buying behavior towards green products: An exploratory study', International journal of management research and business strategy, 3(1), 188-197.

Bashir, N.H.H. (2013) 'Plastic problem in Africa', Japanese Journal of Veterinary Research, vol.61, pp. S1-S11.

Binici, H., Gemci, R., \& Kaplan, H. (2012). Physical and mechanical properties of mortars without cement. Construction and Building Materials, 28(1), 357-361.

Camann, A., Dragsbaek, K., Krol, S., Sandgren, J., \& Song, D. (2010). Properties, recycling and alternatives to PE bags. Worcester Polytechnic Institute, Massachusetts, United States.

CAA (2003, March). Consumer Affairs Authority. Retrieved August 02, 2018, from

http://www.caa.gov.lk/web/images/Act /CAA_Act_E.pdf

CEA (2017, September). Central Environmental Authority. Retrieved December 15, 2017, from www.cea.lk: https://www.cea.lk/web/images/pdf/Po lythene_gazets/2034-33_E.pdf

CEA (2017, September). Central Environmental Authority. Retrieved December 15, 2017, from www.cealk: https://www.cea.lk/web/images/pdf/Po lythene_gazets/2034-34_E.pdf

CEA (2017, September). Central Environmental Authority. Retrieved December 15, 2017, from www.cea.lk: https://www.cea.lk/web/images/pdf/Po lythene_gazets/2034-35_E.pdf

CEA (2017, September). Central Environmental Authority. Retrieved December 15, 2017, from www.cea.lk: https://www.cea.lk/web/images/pdf/Po lythene_gazets/2034-36_E.pdf

CEA (2017, September). Central Environmental Authority. Retrieved December 15, 2017, from www.cea.lk: https://www.cea.lk/web/images/pdf/Po lythene_gazets/2034-37_E.pdf

CEA (2017, September). Central Environmental Authority. Retrieved December 15, 2017, from www.cea.lk: https://www.cea.lk/web/images/pdf/Po lythene_gazets/2034-38_E.pdf 
Diggle, A., \& Walker, T. R. (2020). Implementation of harmonized Extended Producer Responsibility strategies to incentivize recovery of single-use plastic packaging waste in Canada. Waste Management, 110, 20-23.

Dinesh, S., Dinesh, A., \& Kirubakaran, K. (2016). Utilisation of waste plastic in manufacturing of bricks and paver blocks. International Journal of Applied Engineering Research, 2(4), 364-368.

Fernando, R. L. S. (2019). Solid waste management of local governments in the Western Province of Sri Lanka: An implementation analysis. Waste Management, 84, 194-203.

Gogte, M. (2009). Are Plastic Grocery Bags Sacking the Environment? International journal for quality research, 3(4), 363-375.

Goswami, G. (2014). Bio-Plastic from Waste Newspaper. Conference Paper. February.

Gunaratna, D. N. J. C. J. (2012). Analysis on Future Trends of Plastic Recycling in Sri Lanka (Doctoral dissertation, University of Sri Jayewardenepura, Nugegoda).

Hikkaduwa, H. N., Gunawardana, K. W., Halwatura, R. U., \& Youn, H. H. (2015, December). Sustainable approaches to the municipal solid waste management in Sri Lanka. In 6th International Conference on Structural Engineering and Construction Management.

Jassim, A. K. (2017). Recycling of polyethylene waste to produce plastic cement. Procedia manufacturing, 8, 635642.

Kariyawasam, S., Madhuwanthi, A., \& Wilson, C. (2019). The role of stakeholders in managing polythene and plastic waste in coastal cities of Sri Lanka: a case study of the Dehiwala-Mt. lavinia municipal council region. In E3S Web of
Conferences (Vol. 96, p. 02003). EDP Sciences.

Kashiyani, B., Pitroda, J., \& Umrigar, F. S. (2013). Plastic waste: Opportunities for eco-friendly material of bituminous road construction. In National Conference CRDCE13 (pp. 1-8).

Leal Filho, W., Saari, U., Fedoruk, M., Iital, A., Moora, H., Klöga, M., \& Voronova, V. (2019). An overview of the problems posed by plastic products and the role of extended producer responsibility in Europe. Journal of cleaner production, 214, 550-558.

Maroliya, M. K. (2012). A qualitative study of reactive powder concrete using X-ray diffraction technique.IOSR Journal of Engineering (IOSRJEN), 2(9), 12-16.

Marzouk, O. Y., Dheilly, R. M., \& Queneudec, M. (2007). Valorization of post-consumer waste plastic in cementitious concrete composites. Waste management,27(2), 310-318.

McKerlie, K., Knight, N., \& Thorpe, B. (2006). Advancing extended producer responsibility in Canada. Journal of Cleaner Production, 14(6-7), 616-628.

Mourshed, M., Masud, M. H., Rashid, F., \& Joardder, M. U. H. (2017). Towards the effective plastic waste management in Bangladesh: a review. Environmental Science and Pollution Research, 24(35), 27021-27046.

Nielsen, T. D., Holmberg, K., \& Stripple, J. (2019). Need a bag? A review of public policies on plastic carrier bags-Where, how and to what effect? Waste management, 87, 428-440.

Palugaswewa, I. J. K. (2018). Plastic Waste Management in Sri Lanka-Effective policy approaches. IIIEE Master Thesis. 
Pezzi, L., De Luca, P. A., Vuono, D., Chiappetta, F., \& Nastro, A. (2006). Concrete products with waste's plastic material (bottle, glass, plate). In Materials Science Forum (Vol. 514, p. 1753). Trans Tech Publications Ltd.

Rai, B., Rushad, S. T., Kr, B., \& Duggal, S. K. (2012). Study of waste plastic mix concrete with plasticizer. International Scholarly Research Notices, 2012.

Safinia, S., \& Alkalbani, A. (2016). Use of recycled plastic water bottles in concrete blocks. Procedia engineering, 164, 214221.

Sri Lanka Export Development Board (2019). Plastic Products. Retrieved from http://www.srilankabusiness.com/plasti c/index.html

The International Union for Conservation of Nature (2018). Innovative and collaborative: The future of plastic waste management in Sri Lanka. Retrieved from: https://www.iucn.org/news/asia/20180 1 /innovative-and-collaborative-futureplastic-waste-management-sri-lanka

Vanapalli, K. R., Samal, B., Dubey, B. K., \& Bhattacharya, J. (2019). Emissions and environmental burdens associated with plastic solid waste management. In Plastics to energy (pp. 313-342). William Andrew Publishing.

Vineeshiya, M. N., \& Mahees, M. T. M. (2016). Gender perspective of community participation in solid waste management; a case of Balangoda urban council, Sri Lanka. 